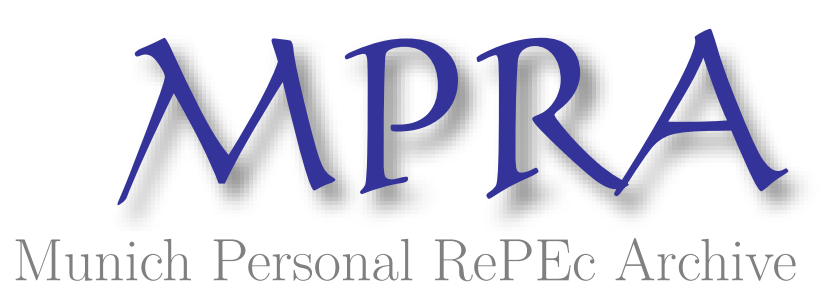

\title{
Epilogue: Back to the future or total recall?
}

Batiz-Lazo, Bernardo

Nortumbria University

2021

Online at https://mpra.ub.uni-muenchen.de/107457/

MPRA Paper No. 107457, posted 30 Apr 2021 14:56 UTC 


\section{Epilogue: Back to the future or total recall?}

\section{Bernardo Bátiz-Lazo ${ }^{1}$}

Published as

The History of Entrepreneurship in Mexico, 219-227

2020 Emerald Publishing Limited

doi:10.1108/978-1-83909-171-120201015

"The problem with the French is that they don't have a word for entrepreneur."

President George W. Bush to Prime Minister Tony Blair, circa 2009 (apocryphal)

\section{The narrative of entrepreneurship}

There is broad agreement to classify innovations as either incremental (continuous) or radical (discontinuous) by determining the degree of change associated with the novel organisational process, product or service (Ettlie, Bridges, and O'Keefe 1984). The process of incremental innovation relates to product improvements, upgrades, and line extensions, mainly reinforcing the existing capabilities of the organisation (Veryzer 1998; Ettlie, Bridges, and O'Keefe 1984). In contrast, radical innovations are developments that relate to fundamental changes in the activities of an organisation, industry or society and represent clear departures from existing practices (Bátiz-Lazo and Woldesenbet 2006; Veryzer 1998). Since the mid-1990s, research of radical innovations has been increasingly explored using the terminology of "disruptive innovations" (Kilkki et al. 2018).

The term "disruptive innovation" or "disruptive technology" roots to the seminal work by Joseph A. Schumpeter (1883-1960). As noted by McGraw (2007), amongst others, Schumpeter's appointment to Harvard in 1932 opened an avenue for Austrian ideas on disequilibrium and business cycles into mainstream economic thought (which had, and to some extent continues to be, dominated by Marshallian ideas of market equilibrium). Schumpeter went further and became one of the first scholars to systematically explore and

\footnotetext{
${ }^{1}$ Comments and suggestions from Niall MacKenzie (Glasgow) are gratefully acknowledged. The usual caveats apply.
} 
debate the role of new technology-based firms in causing economic growth and development.

In 1942 the concept of "creative destruction" was formalised as a process "that incessantly revolutionizes the economic structure from within, incessantly destroying the old one, incessantly creating a new one" (Schumpeter 1942, 83). Schumpeter's ideas on creative destruction argued that innovation causes market dislocations. This allows for the rise of new firms and the corresponding decline of the large incumbent firms whose leadership positions they assume (Spencer and Kirchhoff 2006).

The role of the entrepreneur was to disturb the equilibrium. However, Schumpeter initially resisted the possibility that the Unternehmergeist, German for "entrepreneur-spirit", could reside in large bureaucracies (e.g. Samuelson 2009, 71). Instead it was the remit of individuals or small firms (Schumpeter 1911). This was counterintuitive given that new technology is only possible if there is access to appropriate level of capital or alternatively, credit and financing (Gaffard 2008). The location of entrepreneurial spirit was also questioned by the growing importance of big, diversified, multinational firms as means to explain the rise of US economic hegemony in the early $20^{\text {th }}$ century (Chandler 1990; 1977). Later on, Schumpeter would accommodate both small (called Schumpeter Mark I) and large firms (called Schumpeter Mark II) while the idea of entrepreneurial spirit and its link to "creative destruction" as the engine for economic growth since the Industrial Revolution became pervasive. The narrative of the entrepreneur as an individual or organisation who is the hero of Capitalism was thus born and as discussed in the next section, this narrative has been fully embraced by contributors to this edited book. However, readers will also find evidence within these contributions as to how the discussion on entrepreneurship is moving away from individual actors and into understanding the "entrepreneurial spirit" as a process.

\section{The business history of Mexican entrepreneurship ploughs on}

Research into the business history of Latin America dates to decades following the end of the Second World War. Baughman (1965) and Lauterbach (1965) are the earliest compendia. Since then the field has grown in strength and breath of topics as noted by a number of reviews and edited books (Miller and Dávila 1999; e.g. Dávila 2013; Fernàndez 
Pérez and Lluch 2015). But these contributions should not to be taken as a signal that business history in Latin America is particularly vibrant outside of a small number of countries (BátizLazo 2015). As noted in these contribution as well as in the introduction to this edited book, the role of entrepreneurs and entrepreneurship in the economic development of Latin America has always been something of a black box for scholars to understand, perhaps in part because many of the most successful business enterprises there have been in family hands and largely closed to public scrutiny.

Yet as the contributions to this edited book bear witness, there is somewhat of a rich scholarship and consistent interest to better understand entrepreneurs and entrepreneurship in Latin America including Mexico. This literature is vast and includes notable contributions such as the seminal studies by Jürgen Buchenau (2004) or Mario Cerutti (Marichal and Cerutti 1997; Cerutti and Valdaliso 2004; Cerutti 2009). Allegedly, the business scene is dominated by closely held family business groups (Garrido 1998; Cerutti 2006; Codero and Santìn 1986; Salas Porras 2002; Sargent 2001), which rarely allow access to their corporate archives, or else by a myriad of small businesses, which rarely keep any documentation. Yet these have not been in the way for the publication of notable and insightful biographies (Fernández and Paxman 2000; Paxman 2017; Recio Cavazos 2016), exploring the entrepreneurial in the political space (Purcell and Kaufman Purcell 1977; Camp 1989) or documenting the importance of specific professions such as lawyers to support entrepreneurial endeavour (Recio Cavazos 2017; 2004) .

In it is in the context of that scholarship that the contributions to this edited book explore the coevolution of business enterprises, entrepreneurs and entrepreneurial activity with a much better researched institutional, economic, and social context. As one would expect by the title of this edited book, the cloud map in Figure E.1 suggest that the entrepreneurial spirit and its links to economic development in Mexico rather than individual business actors has been the main theme of the contributions to this edited book. 


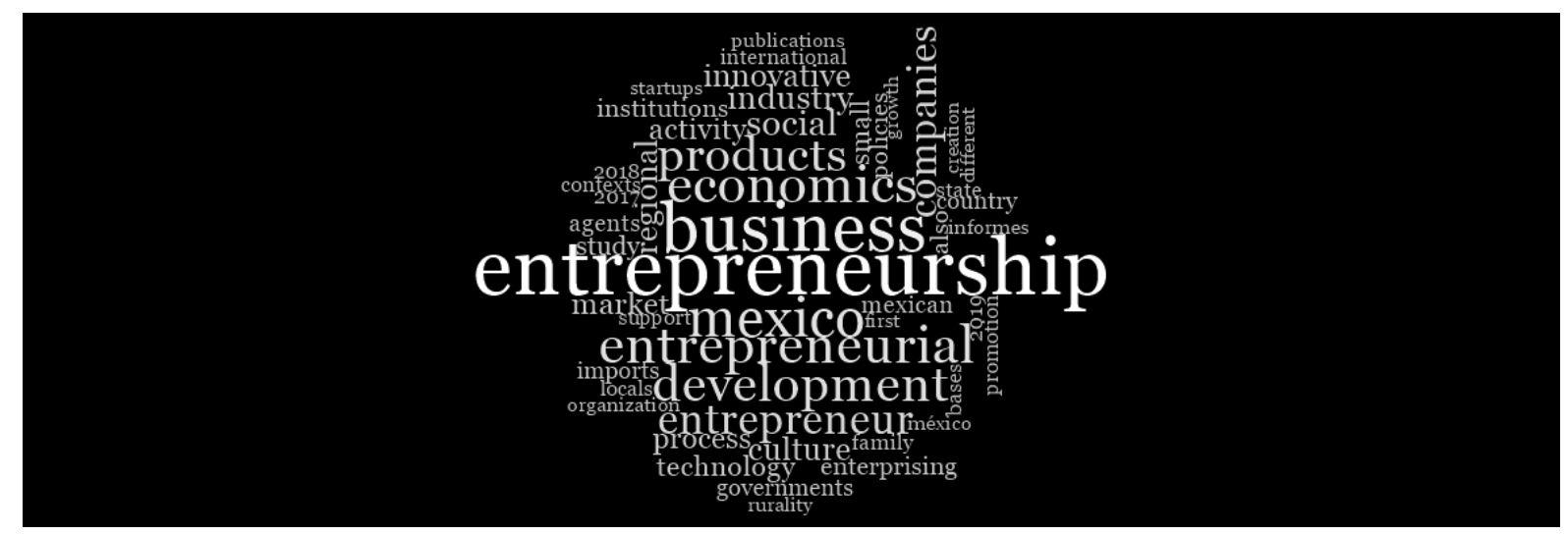

Figure E.1 - A Cloud Map of Entrepreneurship in Mexico

Source: Author own estimates

Figure E.1 further suggests themes in this book dwell around product development. For instance, the case of how the sea urchin became an export commodity (López Torres and colleagues in chapter 6). But more interestingly, how entrepreneurship takes place outside of large urban centres (Riojas and Basurto in chapter 7) and specifically in a rural setting (de Gortari and colleagues in chapter 5). By documenting different aspects of the production processes, industries and process of industrialization, cultures and regions, innovations and technologies, policies and markets, contributions to this edited book offer a mosaic of business histories that enable to distinguish distinctive and shared commonalities with similar processes in other developing countries.

Seldom does Mexican entrepreneurship or indeed Mexican capitalism think of itself to be distinctive or exceptional (e.g. Bizberg and Théret 2012). However, like many emerging markets Mexican business and entrepreneurs also had to navigate great turbulence. As noted by de la Cerda (2007) only a handful of large enterprises see continuity between 1970 and 2000, showing how during that period the Mexican entrepreneurial elite was effectively decimated. Contributions to this edited book provide rich case studies to see this process of from the ground up through stories of success (López Torres and colleagues in chapter 6 ) and industrial demise (Álvarez-Castañón in chapter 8).

A second distinctive feature of Mexican entrepreneurial business history has been the role of foreign-owned business. For most of the twentieth century Mexico has been a net recipient of foreign direct investment (Jones 2005, 256). At times nationalistic policies 
(including the sequestration of asset) and economic instability made Mexico an unattractive place for foreign firms. Yet the role of foreign business was quite important and more so following more economic stability and liberalization over recent decades (Bátiz-Lazo 2013). Perhaps contributions to this edited book or future research could shed more light as to the extent to which foreign firms actually increased opportunities for technological transfer, the competitive structure of the economy, and the impact on the local entrepreneurial spirit.

\section{Considerations for future research}

It was beyond the scope of this chapter to provide full details of the genealogy of creative destruction and entrepreneurial spirit or indeed the evidence to support the view that either (or both) are essential for economic development and growth. Instead the aim of this chapter was to point into the themes that permeate the discussion of contributions to this edited book while, at the same time, highlight the deep roots of these concepts within time, space, and current ideas on national economic wellbeing (see further Montiel and others in chapter 1; Almaraz in chapter 2; Santamaria and colleagues in chapter 3).

This chapter also aims to issue a number of warning when reflecting on future research on entrepreneurs and entrepreneurship in Mexico. First, that although market activities, retailers, large and small organisations, innovation, etc. have been part of human development for centuries they are central to the latter and therefore to the study of entrepreneurial spirit only after the advent of Capitalism and the Industrial Revolution (Mokyr 1992; Allen 2017; Colli 2016). Hence and however interesting it would be to study private enterprise before or during the colonial period (Bátiz-Lazo et al. 2012), it is only appropriate to trace its origins to the advent of capitalism in Mexico during the late $19^{\text {th }}$ century (BátizLazo 2013). Moreover, this background plus the scarcity of archival evidence around individual actors, provide further incentives to on entrepreneurial spirit as a process.

A second warning evolves around mounting evidence to the active role of the state in the genesis and financing of key innovations (Lazonick 2007; Leslie 2000; Bergquist and Söderholm 2011; MacKenzie 2018; Mazzucato 2011; 2013; Lazonick and Mazzucato 2013) as well as to explain how, since the advent of the New Deal in the USA and post-revolutionary governments Mexico (particularly the administrations of Cárdenas del Rio, 1934-1940, and 
Alemán Valdés, 1946-1952) the role of the state extends beyond market regulation, defence and the provision of infrastructure, to engaging directly in the production of capital and consumer goods (Scranton 2006; Freeman and Duvall 1984; FitzGerald 2003; Cárdenas 2003; Kuntz Ficker et al. 2010).

Although conventional wisdom places the responsibility for technological innovations entirely on actors in the private sector, contributions to this book provide some evidence on the overwhelming investment of the Mexican State through government institutions. For instance, it is public universities where basic and applied research takes place. These are the bodies that receive most government grants and key break-throughs take place in say medical science (e.g. Instituto Nacional de Cardiología). It is also public funding that which finances doctoral research abroad (through Conacyt and to a lesser extent, the loan scheme at Banco de México) and supports the arts (Riojas and Basurto in chapter 7). Moreover, all except but two of Mexican presidents in office since 1946 have graduated from taxpayer-funded universities.

In this regard, contributions to this edited book provide some guidance as to how to learn from anecdotal evidence that suggest a break-up in the social pact between the Mexican State and private enterprise during the 1970s and 1980s. Histories that document this break up (the case of the footwear cluster in Álvarez-Castañón in chapter 8) and its reconfiguration around neo-classical economics paradigm (public policy on entrepreneurship by Flores and others in chapter 9) are essential in order to help conceptualise in the future how to organize, direct, evaluate and plan for future State investments that co-operate and co-evolve in a purposeful way with private sector initiatives and build an interesting and dynamic publicprivate partnership.

Further to this point and ss noted by Mazzucato $(2013,3):$ "[d]epicting private business as the innovative force, while the State is cast in the inertia one ... can become a self-fulling prophecy." It will be interesting to document in the future the impact on the entrepreneurial process and indeed growth of government policies and actions after Debt crisis of 1982 and foreign exchange crisis of 1994/1995. More recently, evidence of the precarious macroeconomic health and a lack of dynamic growth and wellbeing before the 2008 crisis seems to acerbate public outcry for the dismemberment of institutions related to innovation and development that took decades to build (e.g. the debacle around the editorial board of $E I$ 
Trimestre Económico). All these seem to have deprived Mexico of important participants in wealth creation.

A third caveat I wish to raise relates to the increased number of contributions that have criticised the excessive interest in the "white heat" moment of innovation as opposed the greater use of resources in keeping machinery and infrastructure running (Russell and Vinsel 2016). Here is perhaps a great avenue for future research of entrepreneurship in Mexico while depicting the emergence of enterprises that actually help to keep the economy going. It is likely that in a post 1980 s world, many of these enterprises appeared while the State retrenched from economic activity.

Fourth and final, the study of entrepreneurs and entrepreneurship from an business history perspective seems fragmented and lacking conceptual clarity (Wadhwani and Lubinski 2017). In this regard, the contributions in this collection have moved our understanding of Mexican entrepreneurship towards providing greater clarity but more work is to be done. Indeed I have pointed to some of the potential avenues this future research could take while building on the contributions to this edited book such as deepening our understanding of entrepreneurship in the advent of capitalism to Mexico, how these process changed during post-revolutionary governments and again after financial debacles of the 1980s and 1990s. All this can shed new light for domestic and international scholars looking to learn more about the role of the State, family business, and innovation in Mexican enterprise.

Once again I congratulate the editors and individual authors for bringing these contributions to light while, at the same time, invite others to build on these contributions and push conceptual and empirical agendas forward.

\section{References}

Allen, Robert. 2017. The Industrial Revolution: A Very Short Introduction. Oxford and New York: Oxford University Press.

Bátiz-Lazo, Bernardo. 2013. "The Adoption of US-Style Business Education in Mexico, 19452005." América Latina En La Historia Económica 20 (1 (enero-abril)): 158-98.

- - . 2015. "A Dainty Review of the Business and Economic History of Chile and Latin America." Estudios de Economia 42 (2 Year 20): 5-16.

Bátiz-Lazo, Bernardo, J Julián Hernández Borreguero, Joan Carles Maixé-Altés, and Miriam 
Núñez Torrado. 2012. "Adoption, Diffusion and Appropriation of Double Entry Bookkeeping in Mexico and Spain: A Related but under-Investigated Development." América Latina En La Historia Económica 19 (3): 164-205.

Bátiz-Lazo, Bernardo, and Kassa Woldesenbet. 2006. "The Dynamics of Product and Process Innovation in UK Banking." International Journal of Financial Services Management 1 (4): 400-421.

Baughman, James P. 1965. "Recent Trends in the Business History of Latin America." Business History Review 39 (4): 425-38.

Bergquist, Ann-kristin, and Kristina Söderholm. 2011. "Green Innovation Systems in Swedish Industry, 1960-1989." Business History Review 85 (4): 677-98.

Bizberg, Ilan, and Bruno Théret. 2012. "La Diversidad de Los Capitalismos Latinoamericanos: Los Casos de Argentina, Brasil y México." Noticias de La Regulación 61 (4): 1-22.

Buchenau, Jürgen. 2004. Tools of Progress: A German Merchant Family in Mexico City, 1865Present. Albuquerque: University of New Mexico Press.

Camp, Roderic. 1989. Entrepreneur and Politics in Twentieth-Century Mexico. Oxford: Oxford University Press.

Cárdenas, Enrique. 2003. "El Proceso de Industrialización Acelerade En México (19291982)." In Industrialización y Estado En La América Latina: La Leyenda Negra de La Posguerra, edited by Enrique Cárdenas, José Antonio Ocampo, and Rosemary Thorp, 277-320. México, D.F.: El Trimestre Económico - Fondo de Cultura Económica.

Cerutti, Mario. 2006. Empresas y Grupos Empresariales En América Latina, España y Portugal. Monterrey: Universidad Autónoma de Nuevo Leon-Universidad de Alicante.

- - . 2009. "Fertilidad Empresarial En Monterrey (1885-1930)." In La Economía Mexicana En 19 Miradas, edited by Daniel Flores Curiel, María de Lourdes Treviño Villareal, and Jorge N Valero Gil. México, D.F.: Miguel Angel Porrúa/Universidad Autónoma de Nuevo León.

Cerutti, Mario, and Jesús María Valdaliso. 2004. "Monterrey y Bilbao (1870-1914): Empresariado, Industria y Desarrollo Regional En La Periferia." História Económica \& História de Empresas 7 (1): 47-74.

Chandler, Alfred D. 1977. The Visible Hand. Cambridge MA and London: The Belknap Press (Harvard University Press).

- - . 1990. Scale and Scope: The Dynamics of Industrial Capitalism. Cambridge, MA: Harvard University Press.

Codero, Salvador, and Rafael Santìn. 1986. “Concentración, Grupos Monopolicos y Capital Financiero Del Sector Privado En México." In Grupos Económicos y Organizaciones Empresariales En México, edited by Julio Labastida, 163-213. México, D.F.: Alianza Editorial.

Colli, Andrea. 2016. Dynamics of International Business : Comparative Perspectives of Firms, Markets and Entrepreneurship. Abingdon, Oxon: Routledge.

Dávila, Carlos. 2013. "The Current State of Business History in Latin America." Australian Economic History Review 53 (2): 109-20. 
Ettlie, John.E., William.P. Bridges, and Robert.D. O'Keefe. 1984. “Organization Strategy and Structural Differences for Radical versus Incremental Innovation." Management Science 30 (6): 682-95.

Fernández, Claudia, and Andrew Paxman. 2000. El Tigre : Emilio Azcárraga y Su Imperio Televisa. Mexico City: Grijalbo.

Fernàndez Pérez, Paloma, and Andrea Lluch. 2015. "Familias Empresarias y Grandes Empreas Familiares En América Latina y España: Una Visión de Largo Plazo." Bilbao: Fundación BBVA.

FitzGerald, E V K. 2003. "La CEPAL y La Teorìa de La Industrializaciòn Por Medio de La Sustuciòn de Importaciones." In Industrializaciòn y Estado En Amèrica Latina, edited by Enrique Càrdenas, Josè Antonio Ocampo, and Rosemary Thorp, 85-137. Mèxico, D. F.: El Trimestre Econòmico - Fondo de Cultura Ecònomica.

Freeman, John. R, and Raymond D Duvall. 1984. "International Economic Relations and the Entrepreneurial State." Economic Development and Cultural Change 32 (2): 373-400.

Gaffard, Jean-luc. 2008. "Innovation, Competition, and Growth: Schumpeterian Ideas within a Hicksian Framework." Journal of Evolutionary Economics 18 (3-4): 295-311.

Garrido, Celso. 1998. "El Liderazgo de Las Grandes Empresas Industriales Mexicanas." In Grandes Empresas y Grupos Industriales Latinoamericanos, edited by Wilson Peres and Celso Garrido, 397-470. México: Siglo XXI-CEPAL.

Jones, Geoffrey. 2005. Multinationals and Global Capitalism: From Nineteenth to the Twenty-First Century. Oxford: Oxford University Press.

Kilkki, Kalevi, Martti Mäntylä, Kimmo Karhu, Heikki Hämmäinen, and Heikki Ailisto. 2018. "Technological Forecasting \& Social Change A Disruption Framework." Technological Forecasting \& Social Change 129 (November 2016): 275-84.

Kuntz Ficker, Sandra, Bernd Hausberger, Carlos Marichal, and Enrique Cárdenas. 2010. Historia Económica General de México: De La Colonia a Nuestros Días. Ciudad de Mexico: El Colegio de México \& Secretaría de Economía.

la Cerda, José de. 2007. "The Leading Business Companies of Mexico 1975-2005: Survivors and out Performers of the Global Economic Revolution." PhD in Business. Chicago: Benedictine University.

Lauterbach, Albert. 1965. "Management Aims and Development Needs in Latin America." Business History Review 39 (4): 557-88.

Lazonick, William. 2007. "The US Stock Market and the Governance of Innovative Enterprise." Industrial and Corporate Change 16 (6): 983-1035.

Lazonick, William, and Mariana Mazzucato. 2013. "The Risk-Reward Nexus in the Innovation-Inequality Relationship: Who Takes the Risks? Who Gets the Rewards?" Industrial and Corporate Change 22 (4): 1093-1128.

Leslie, Stuart.W. 2000. "The Biggest 'Angel' of Them All: The Military and the Making of Silicon Valley." In Understanding Silicon Valley: The Anatomy of an Entrepreneurial Region, edited by Martin Kenney, 48-70. Stanford: Stanford Unversity Press.

MacKenzie, Niall G. 2018. “Creating Market Failure: Business-Government Relations in the 
British Paper-Pulp Industry, 1950-1980." Business History Review 92 (4): 719-41.

Marichal, Carlos, and Mario Cerutti. 1997. Historia de Las Grandes Empresas En México, 1850-1930. México, D.F.: Fondo de Cultura Económica.

Mazzucato, Mariana. 2011. "The Entrepreneurial State." Soundings 49 (49): 131-42.

- - . 2013. The Entrepreneurial State: Debunking Public vs. Private Sector Myths. London: Anthem Press.

McCraw, Thomas.K. 2007. Prophet of Innovation: Joseph Schumpeter and Creative

Destruction. Cambridge, Massachusetts: The Belknap Press of Harvard University Press.

Miller, Rory, and Carlos Dávila. 1999. "Introduction." In Business History in Latin America:

The Experience of Seven Countries, edited by Rory Miller and Carlos Dávila. Liverpool: Liverpool University Press.

Mokyr, Joel. 1992. The Lever of Riches: Technological Creativity and Economic Progress. Oxford and New York: Oxford University Press.

Paxman, Andrew. 2017. Jenkins of Mexico. How a Southern Farm Boy Became a Mexican Magnate. Oxford and New York: Oxford University Press.

Purcell, John, and Susan Kaufman Purcell. 1977. "Mexican Business and Public Policy." In Authoritarianism and Corporatism in Latin America, edited by James Malloy. Pittsburgh: University of Pittsburgh Press.

Recio Cavazos, Gabriela. 2004. "Lawyers' Contribution to Business Development in Early Twentieth-Century Mexico." Enterprise and Society 5 (2): 281-306.

- - . 2016. Don Eugenio Garza Sada : Ideas, Acción, Legado.

-- - 2017. El Abogado y La Empresa : Una Mirada Al Despacho de Manuel Gómez Morin, 1920-1940. Mexico City: Universidad Nacional Autónoma de México \& Instituto de Investigaciones Jurídicas.

Russell, Andrew, and Lee Vinsel. 2016. "Innovation Is Overvalued. Maintenance Often Matters More."

Salas Porras, Alejandra. 2002. "Avenidas de Desarrollo de Los Grandes Grupos Empresariales Mexicanos." Revista Mexicana de Sociologia 64 (1): 141-85.

Samuelson, Paul A. 2009. "Advances in Total Factor Productivity and Entrepreneurial Innovation." In Entrepreneurship, Growth, and Public Policy, 71-78. Cambridge and New York: Cambridge University Press.

Sargent, John. 2001. "Getting to Know the Neighbors: 'Grupos' in Mexico." Business Horizons, no. Nov-Dec: 16-24.

Schumpeter, Joseph A. 1911. The Theory of Economic Development. London: Transaction Publishers (1981).

- - . 1942. Capitalism, Socialism, and Democracy. Third. New York: Harper \& Row.

Scranton, Philip. 2006. "Technology, Science and American Innovation." Business History 48 (3): 311-31.

Spencer, Aron.S., and Bruce. A. Kirchhoff. 2006. "Schumpeter and New Technology Based 
Firms: Towards a Framework for How NTBFs Cause Creative Destruction." International Entrepreneurship and Management Journal 2 (1): 145-56.

Veryzer, Robert W. 1998. "Discontinuous Innovation and the New Product Development Process." Journal of Product Innovation Management 15 (4): 304-21.

Wadhwani, R. Daniel, and Christina Lubinski. 2017. "Reinventing Entrepreneurial History." Business History Review 91 (4): 767-99. 